\title{
The Battle between Toilets \& Minds
}

\author{
Jaideep Kharb \\ Ex. Assistant Director, Planning \& Capacity Building, Association of Municipalities \& Development Authorities, New Delhi
}

\begin{abstract}
Mahatma Gandhi said in 1925 that for India "Sanitation is more important than independence,". Indian Government is committed to achieve the goal of total sanitized country on or before $150^{\text {th }}$ Birth Anniversary of Mahatma Gandhi (2 ${ }^{\text {nd }}$ October 2019) through Swatch Bharat Abhiyan Campaign. But author is worried about the way which has been chosen to achieve this goal. People still believe in cultural taboos. Many people don't build or use toilets due to many beliefs or age old practices. In rural areas one can easily found that three out four persons in a household prefer to go in open for defecation while having a toilet in their premises. If proper precautions will not be taken then it will also not give the significant impact as of earlier policies/programmes. For making 100 percent sanitized open defecation free India, Government should plan to hit people's mind by focusing on more and more behavioral change along with constructing toilets. If detailed survey is conducted in rural India the figure of open defecation will rise between $5-10$ percent. Because from most of rural households one or more members are going in open, even having toilets in their premises, but these are considered in different category.
\end{abstract}

Keywords:

\section{Introduction}

India ranks among the worst countries in the world in terms of access to sanitation. The World Health Organization (WHO) and United Nations Children's Fund (UNICEF) estimate that there are more than 620 million people practicing open defecation. It is the biggest national shame, anguish, and sorrow. Census data (2011) reveals that the percentage of households having access to television and telephones in rural India exceeds the percentage of households with access to toilet facilities. According to WHO and UNICEF's Joint Monitoring Programme for Water Supply and Sanitation (JMPWSS), India will achieve the millennium development goals (MDGs) on sanitation only by 2054 , by going through the present pace of progress.

\section{Urban Sanitation}

According to 65th round survey of National Sample Survey Organization (NSSO) 77 percent(70.9 percent as per 2011 census) households have septic tank/flush latrines, 8 percent pit latrines, 1.6 percent service latrines, 1 percent other latrines, and 11 percent(12.6 percent as per 2011 census) are residing without any latrines in urban India. Out of these about 58 percent households have individual latrines, 24 percent households are using sharedlatrines, and 6.5 percent use community/public latrines.

\section{Rural Sanitation}

According to 2011 census 67.3 per cent households do not have access to toilets in rural India. A recent survey carried out in rural areas of 13 districts of five states (Rajasthan, Madhya Pradesh, Uttar Pradesh, Haryana and Bihar) by Research Institute of Compensate Economics (RICE) on Sanitation Quality Use Access and Trends (SQUAT). They found that a full 40 per cent of households in the sample that had a latrine had at least one person who was still defecating in the open. This number was the highest in Rajasthan (57 per cent)and the lowest in Haryana (35 per cent). In all over a quarter of men with a toilet and 17 per cent of women with a toilet defecated in the open. Those who had a toilet but defecate in the open are 74 per cent gave" pleasure, comfort, and convenience" as the reason for this, and another 14 percent said it was because of "habit, tradition, and because they have always done so." The survey findings also show that the lack of money to build a toilet is not the only cause which prevent to building a toilets; but a large parts of the population do not understand the correlation between good health and using toilets.

\section{Slum Scenario}

Out of every six urban people one is residing in slum. Census 2011 reveals that 68 million (17\%) of country's population is residing in slums. The condition of sanitation in slums is more terrible. Census data reveals that 34 percent slum households don't have toilet but 72.7 percent households have phones, of which 63.5 percent have mobile phones and 10.4 percent slum households have computers.

\section{Indian Railways}

Roughly almost 23 million passengers daily travel in Indian Railway. It is among the longest railway networks in the world. At the same time it is world's largest open toilet. It is not even calculated in census in the category of open defecation. If someone has to wait for train at some station it will be amongst a phatic experience of his life. The situation became worse at morning hours along with the suburb of the cities. No one can dare to see out of his/her window. We have been living with it from generations and this is the hard fact. It is really a disgrace to all of us in India.

\section{Schools Sanitation}

Almost 28 million school children across India do not have access to school toilet facilities. Adequate, well-maintained water supply and sanitation facilities in schools encourage children to attend school regularly and help them to achieve their educational goals. Adolescent girls are especially vulnerable to dropping out, as many are reluctant to continue their schooling because toilet facilities are not separate \&safe or simply not available. The number of schools 


\section{International Journal of Science and Research (IJSR) \\ ISSN (Online): 2319-7064}

Index Copernicus Value (2013): 6.14 | Impact Factor (2014): 5.611

having separate toilet facility for girls has increased from 4.20 lakh $(37.4 \%)$ in $2005-06$ to 10.05 lakh $(72.16 \%)$ in 2011-12. However, there are number of issues about the quality of construction of these facilities, functionality and use. Inadequate water supply and sanitation in schools are health hazardous and adverse effect on school attendance, retention and educational performance.

\section{Public Toilets}

Using a public toilet in India is not a good experience you look forward to. It can be so bad that invariably it makes you better to go in open. Local Bodies eventually build toilets and forget their responsibility to clean and maintain it regularly. The lack of monitoring of their cleanliness is always a major issue in India. Sometime the budget is not allocated for their cleanliness \& maintenance. Toilets are built as per common design for all users viz. Children, Women andMen and also for physically challenged persons. Most of the toilets were found operational only during the day time and kept locked at night. Sometime toilets were found in areas with very little foot-traffic, away from slums, market areas, or bus stops, and were sometimes hidden behind large walls or trees or without proper signage.

Users are also very irresponsible. They even don't bother to press the flush after use. People always use them just for privacy or in a very emergency condition when there is no other option left out. Basically it comes from a thinking that says public space DOESNT BELONG to them. This can be changed that public space BELONGS TO EVERYONE by way of contact with the authorities concerned and through sensitization programs as well as a parallel severe \& immediate penalization framework for polluting the environment.

\section{Sikkim- An Example for Adoption}

Sikkim became the first State in India to achieve 100 percent sanitation coverage under the Nirmal Bharat Abhiyaan launched on 9 February 2014. Sikkim achieved 100 per cent sanitation in rural and urban households, schools, sanitary complexes and Aanganwadi centers. The initiatives taken by Sikkim State Government should be widely published so that this may motivate the other states to achieve the same stage. According to a total evaluation study conducted by the Planning Commission in 2013, Sikkim emerged with the best performing gram panchayats and maintenance of sanitation facilities.

\section{Causes \& Impacts}

The impact of inadequate sanitation on health leads to a number of financial and economic costs director indirect. Direct, Cost involves medical costs associated with treating sanitation-related diseases. Indirect cost is huge in terms of reduced or loss of productivity and the government costs of providing health services. In spite of this sanitation also leads to time and effort losses due to distant or inadequate sanitation facilities, lower product quality resulting from poor water quality, reduced income from tourism (due to high risk of contamination and disease) and cleanliness costs. Increases in female literacy (due to increased school attendance where proper sanitation facilities exist) also contribute to economic growth.

\section{A. Economic Causes}

India spends $\$ 48$ on per capita sanitation which is worse situation among many other Asian countries. The annual per person loss from poor sanitation is \$9.3 in Vietnam, \$16.8 in the Philippines, \$28.6 in Indonesia, and \$32.4 in Cambodia. This shows the urgency to improve sanitation.

According to The Economic Impacts of Inadequate Sanitation in India, inadequate sanitation causes India considerable economic losses, equivalent to 6.4 percent of India's GDP in 2006. The study analyzed the evidence on the adverse economic impacts of inadequate sanitation, which includes costs associated with death and disease, accessing and treating water, and losses in education, productivity, time, and tourism.

\section{B. Social Causes}

In India sanitation is a very much neglected subject even no one wants to discuss on it. That's why government schemes/programmes doesn't give the expected outcomes. But Along with financial constraints people are not ready to adapt. States having a good literacy rate are also not aware of its necessity or one can say benefits. In rural India people used to construct toilet in a much neglected corner of the house. They consider it very odd if it is near to place of deity or kitchen. Even the households which have toilets from last 4 to 5 or more years that is only used by female members of the family, handicapped or used by old people, Young man use it only in case of emergency. It is not due to consciousness for hygiene but for privacy of women. Some households are only construct toilet in their house before coming of daughter-in-law or disability of elderly people to go to open. Gents family members used to feel pleasure while going into the open. This is also the part of their morning walk.

\section{Economic Cause}

In India most of people don't willing to pay even a very nominal user fee applied by pay \& use toilets until there is any option left. Very often one can see that people are going to open rather than using pay \& use toilet. Sometime due to financial inefficiency of household and ignorance about government subsidized schemes to build a toilet may became a cause to increase the open defecation.

\section{Climatic Impact}

Charles Darwin was an English geologist. Who has published his famous book "Origin of Species" in 1859. In his book he has given the theory of "Survival to Fittest" means the creature that can moderate itself according to climate will only survive on this earth. Man has succeeded to accommodate in very odd climatic conditions due to innovation in technology. But still his presence in climatic odd situation is not so much predominantly. By seeing figure below one can understand the climatic impact on toilets. Out of 11 hilly states only one has less than 40 percent coverage of toilets. Chilling cold climate doesn't allow people to defecate in open. 
International Journal of Science and Research (IJSR)

ISSN (Online): 2319-7064

Index Copernicus Value (2013): 6.14 | Impact Factor (2014): 5.611

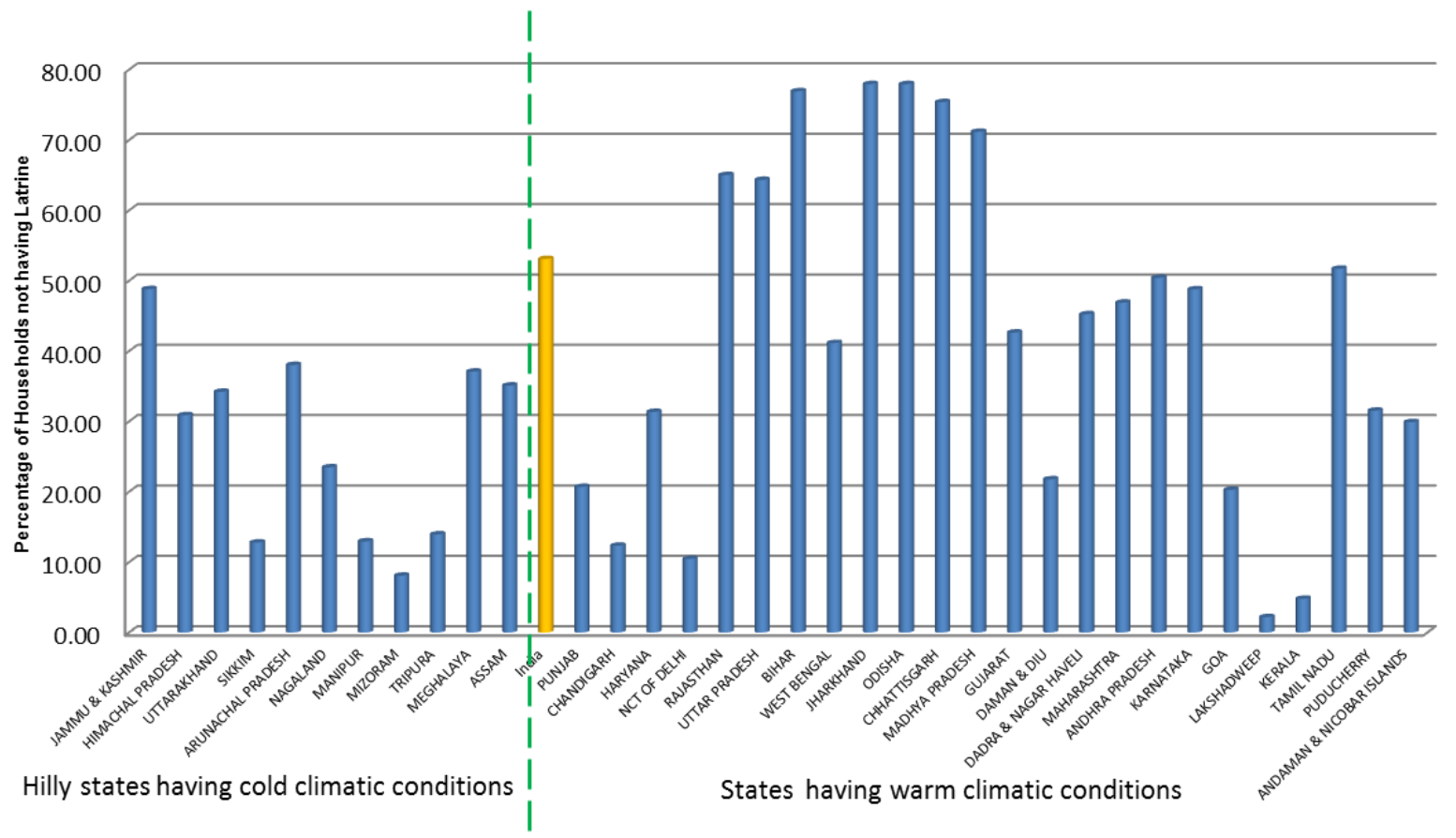

\section{E. Health Hazards}

Poor sanitation causes death of a number of persons every year. India has a massive problem of open defecation.Sanitation is directly related with health. It is estimated that 1 in every 10 deaths in rural India, is linked to poor sanitation and hygiene. India loses more than 600,000 children under the age of five year due to diarrhea and pneumonia almost $30 \%$ of the global total. Bacteriological contamination, the absence of toilet-use and woefully poor personal and communal hygiene (including no habitual hand-washing with soap at critical times) exacerbate both of these killers; $88 \%$ of diarrhea deaths are linked to incomplete water and sanitation service provision.

According to UNICEF about 48 per cent of children in India are suffering from some degree of malnutrition. Diarrhea and worm infection are two major health conditions that affect school age children impacting their learning abilities.

\section{Some Initiatives}

Along with government some National \& International Organizations like WHO, UNICEF, Sulabh International, and Water Aid etc. are also doing very remarkable job in this field. These organizations carried out time to time various research \& studies. These also help to overcome the cultural aversion about toilets.Several non-profit organizations, such as Arghyam (in Karnataka), Water Aid and Sulabh International, are working to educate communities about the necessity of sanitation. In 1968, Sulabh began to promote its twin-pit latrine design, which requires just 1.5 to 2 liters of water to flush, compared to the 12 to 15 liters that modern toilets use up per flush. One can easily find "Sulabh Complex" even in class IV town or any other tourist place. But they are primarily focusing only on urban areas.

\section{Some Creative Suggestions:}

\section{- Transformation of the toilet Architecture}

All buildings should be functional and aesthetically beautiful. "No one has given any thought to the toilets as a piece of art," Determined to prove that with beauty comes respect, toilets should be a striking landmark these should be purposefully designed by using funky shapes and bright colors, so, that the customers take time. It have been widely seen if you build something beautiful, people will take care of it.

\section{- Implement a business model}

For an affordable price the general public can go to a toilet and access clean, safe and hygienic sanitation facilities/services that before simply didn't exist. The space surrounding the toilet can be rented to local business man who provide a range of services like hair cutting, shoe polishing and money transfer or to advertise to a captive audience, bigger businesses houses also pay for wall space to promote their brands. Income from user charges, rent revenue and advertising deals covers all the overheads of each toilet.

\section{- Awareness about sanitation and hygiene}

Using innovative mass media campaigns, cultural taboos which keep the toilet business a hush-hush topic of conversation till date some public figureshave also brought to discuss on these taboos, including behavioral changes is the objective which underpins everything within the strategy.

\section{Conclusion}

It is very shameful that India is among the most rapidly growing economies of the world but still its 51 percent people are defecating in open that is world's 60 percent. Just building toilets alone without focusing on behavioral change is not going to work. The sanitation policies and 


\section{International Journal of Science and Research (IJSR) \\ ISSN (Online): 2319-7064 \\ Index Copernicus Value (2013): 6.14 | Impact Factor (2014): 5.611}

programmes are more focused on building toilets rather than to motivate people to use it. Sanitation problem has been diagnosed as a lack of access to toilets; rather than focusing on behavioral change. If someone think that people'sbehavior will automatically change with improving literacy, the idea is not going to work looking to 2011 census figures. The diagram given below showsthe relation between the literacy rate and percentage of households having toilet facilities. One can easily identify that there are some states having 65-70 percent literacy but are also having $60-70$ percent deficit in toilets facilities.

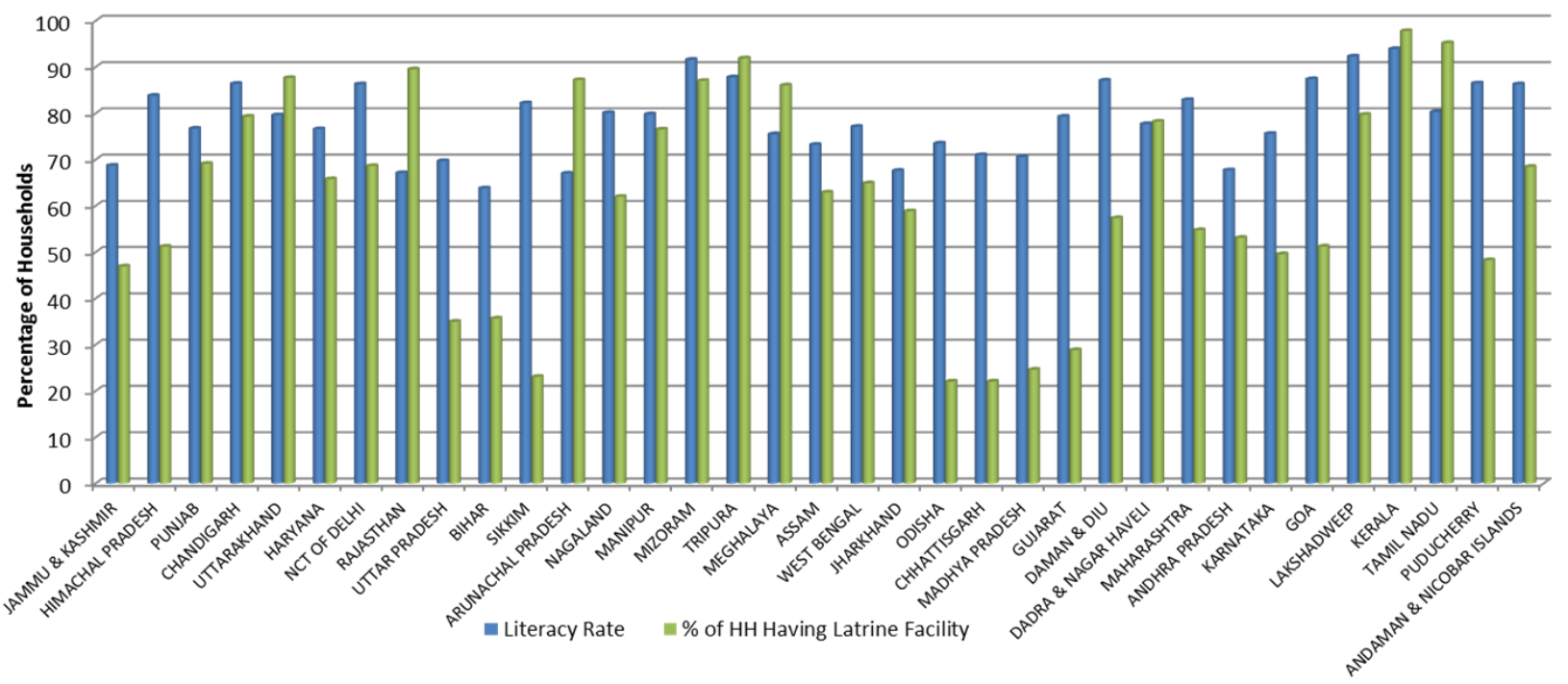

Many Sanitation Policies/Programmes are drafted just focusing on BPL families. But 100 percent sanitation goal will be achieved when every citizen opt it as a campaign (Abhiyan).The efforts should be a joint initiative of all Educational Institutions, Government Institutions, Private Organization, Public Sector Undertaking (PSUs), Non Governmental Organizations (NGOs), Community Based Organizations (CBOs), Self Help Groups (SHGs) etc. In whatever field they are working safe sanitation should be in their agenda. A large scale Information, Education and Communication (IEC) programmes should be organized to make every people aware about safe sanitation. National Celebrities from each sector should present example before people because people always follow their role model that will make greater impact in their mindset. Safe sanitation slogans/pictures should be at every packed material. Messages should be spread through print and electronic media. "Swatchata March" should be organized by local government in every village/city including students, administrators and politicians etc. Continuous hammering on people's mind will help the government to achieve the goal of 100 percent sanitation in India.

\section{References}

[1] A report on "Sanitation for All- Still a Long Way to go" Published by Water Aid India (2006).

[2] Kharb, Jaideep, Sanitation for All (2014), an article published in AMDA Bulletin, Vol IV, Issue 1.

[3] Census of India, 2011.

[4] http://www.forbes.com/sites/ashoka/2013/01/28/whythe-sanitatio-business-is-good-business/

[5] http://www.indiasanitationportal.org/18173

[6] http://riceinstitute.org/wordpress/sanitation/

[7] http://scroll.in/article/656661/How-Sikkim-built-toiletsfor-all- $\% \mathrm{E} 2 \% 80 \% 93$-and-why-the-rest-of-India-isstruggling-to-catch-up
[8] http://infochangeindia.org/environment/news/sikkimbecomes-first-state-to-achieve-100-sanitation.html

[9] http://www.thehindu.com/features/metroplus/article254 3188.ece

[10] http://www.ndtv.com/article/india/indian-rail-is-worlds-largest-open-toilet-jairam-ramesh-248318

[11] http://www.transparentchennai.com/wpcontent/uploads/2011/05/Public-Toilets-TransparentChennai-Issue-Brief.pdf

[12] http://www.sulabhtoiletmuseum.org/old/pg02.htm\#TOP

[13] http://www.unicef.org/india/media_8660.htm

[14] http://www.poo2loo.com/fact-and-stats.php

[15] http://en.wikipedia.org/wiki/Charles_Darwin

[16] http://www.sociologyofsanitation.com/honbleguests/sessionspeakers/sanitation-health-anddevelopment-deficit-in-india-a-sociological-perspective/

[17] http://www.wsp.org/featuresevents/features/inadequatesanitation-costs-india-equivalent-64-cent-gdp 